\title{
Late Maastrichtian dinoflagellate cysts from the Cerro Butaló section, southern Mendoza province, Argentina
}

\author{
MERCEDES B. PRÁMPARO ${ }^{1} \&$ OSCAR H. PAPÚ $^{2}$ \\ ${ }^{1}$ Unidad de Paleopalinología. Instituto Argentino de Nivología, Glaciología y Ciencias ambientales (IANIGLA)- CRICYT, CONICET. \\ C.C.131 (5500), Mendoza, Argentina (e-mail: mprampar@lab.cricyt.edu.ar) \\ ${ }^{2}$ Gutenberg 5121, Guaymallén (5521), Mendoza, Argentina (e-mail: opapú@hotmail.com)
}

\begin{abstract}
The Late Cretaceous Atlantic transgression in southern South America is recorded in western Argentina in the upper part of the Malargüe Group. The Cerro Butaló section outcrops in the south of Mendoza Province and comprises sediments attributable to the Jagüel and Roca formations. Well-preserved palynological associations were recovered from this section. Only the marine associations - dinoflagellate cysts, acritarchs and green algae - are considered in this article. A Late Maastrichtian age is suggested for the Roca and Jagüel formations based on the presence of Deflandrea galeata and Disphaerogena carposphaeropsis in the lower part of the section and Glaphyrocysta perforata in the upper part of the section and the absence of any Danian cosmopolitan markers. Variations in dinoflagellate cyst species diversity throughout the section permit recognition of two intervals that are probably related to different palaeoenvironmental conditions connected with episodes of sea-level fluctuation. J. Micropalaeontol. 25(1): 23-33, April 2006.
\end{abstract}

KEYWORDS: Late Maastrichtian, dinoflagellate cysts, biostratigraphy, Southern Mendoza, Argentina

\section{INTRODUCTION}

The Neuquen Basin is a depocentre in western Argentina with deposits ranging in age from the Late Triassic to the Palaeogene. Three major sedimentary Supercycles are represented: 'Jurásico' (Late Triassic-Late Jurassic); 'Andico' (Late Jurassic-Early Cretaceous); and 'Riograndico' (Late Cretaceous-Paleocene) (Groeber, 1947). The present study focuses on the upper part of the Riográndico Supersequence known as the Malargüe Group (Uliana \& Dellape, 1981).

During the Campanian-Maastrichtian, the tectonic evolution of the Neuquen Basin changed abruptly with the Mirano orogenic phase, and a generalized marine transgression from the Atlantic Ocean took place in southern South America. The Andean magmatic arc separated southern South America from the Pacific Ocean, a compressional event produced the uplift of the back-arc and a foreland stage started in the Neuquen Basin. In the southern Mendoza segment of the Neuquen Basin, Upper Cretaceous sediments accumulated within a relatively confined back-arc setting. Deposition occurred in an elongated $120 \mathrm{~km}$ wide seaway (NNW-SSE) between the magmatic arc in Chile and the gently subsiding South American foreland to the east.

In the Andean area the Malargüe Group comprises the Loncoche, Jagüel, Roca and Pircala Formations (Fig. 1). The Cerro Butaló section crops out at $35^{\circ} 50^{\prime} \mathrm{S}$ and $69^{\circ} 40^{\prime} \mathrm{W}$ (Fig. 2), in the southern Mendoza Province, western Argentina and comprises sediments belonging to the Malargüe Group. The Jagüel Formation is $25 \mathrm{~m}$ thick at Cerro Butaló and is characterized by green laminated shales with interbedded calcareous sandstones, following Legarreta et al. (1989). This is overlain by the Roca Formation which comprises $30 \mathrm{~m}$ of limestone with abundant fragments of bivalves and gastropods, followed by $20 \mathrm{~m}$ of pelitic sandstone. The Pircala Formation $(30 \mathrm{~m}$ thickness) is composed of massive brown-green claystones and siltstones. Near the top the lithology changes to red coarse-grained sandstones; occasional ashfalls are preserved as pyroclastic strata or as a mixture of pyroclastic and epiclastic sediments recycled and deposited by rivers.

The Malargüe Group in the south of Mendoza Province can be divided into five depositional sequences (Parras et al., 1998). The Jagüel and Roca Formations correspond to the third depositional sequence deposited in a subtidal to intertidal environment (Fig. 1). Parras et al. (1998) indicate that in this

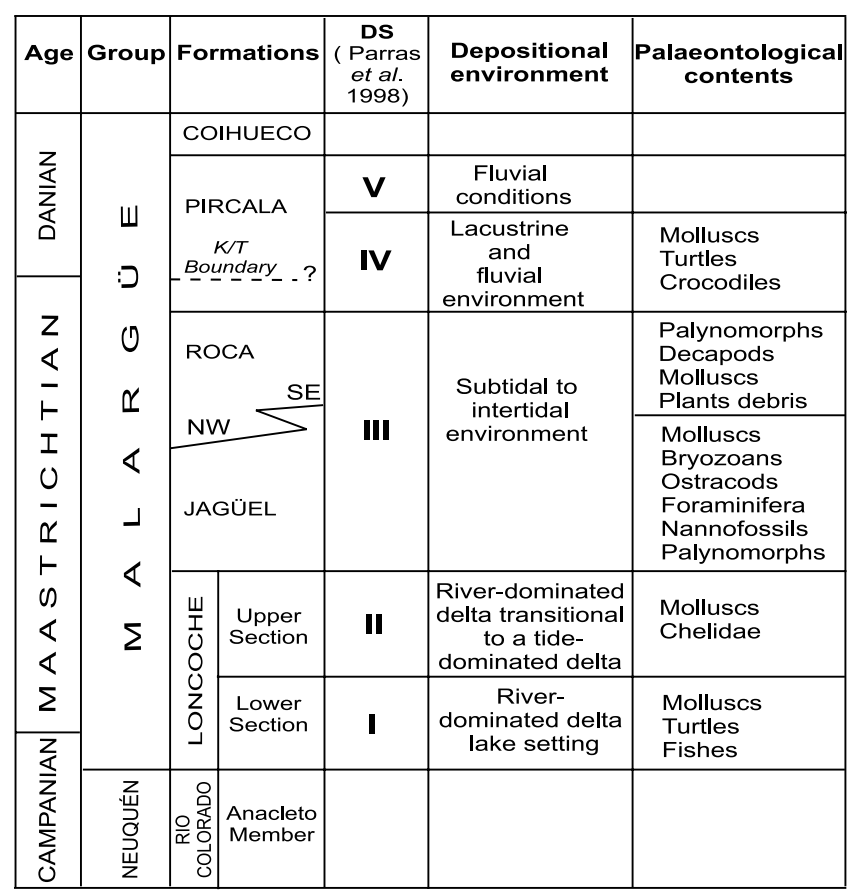

Fig. 1. Generalized integrated stratigraphical column of the Malargüe Group for the south of Mendoza Province with the depositional sequences (DS), corresponding depositional environments and palaeontological contents (after Parras et al., 1998). 


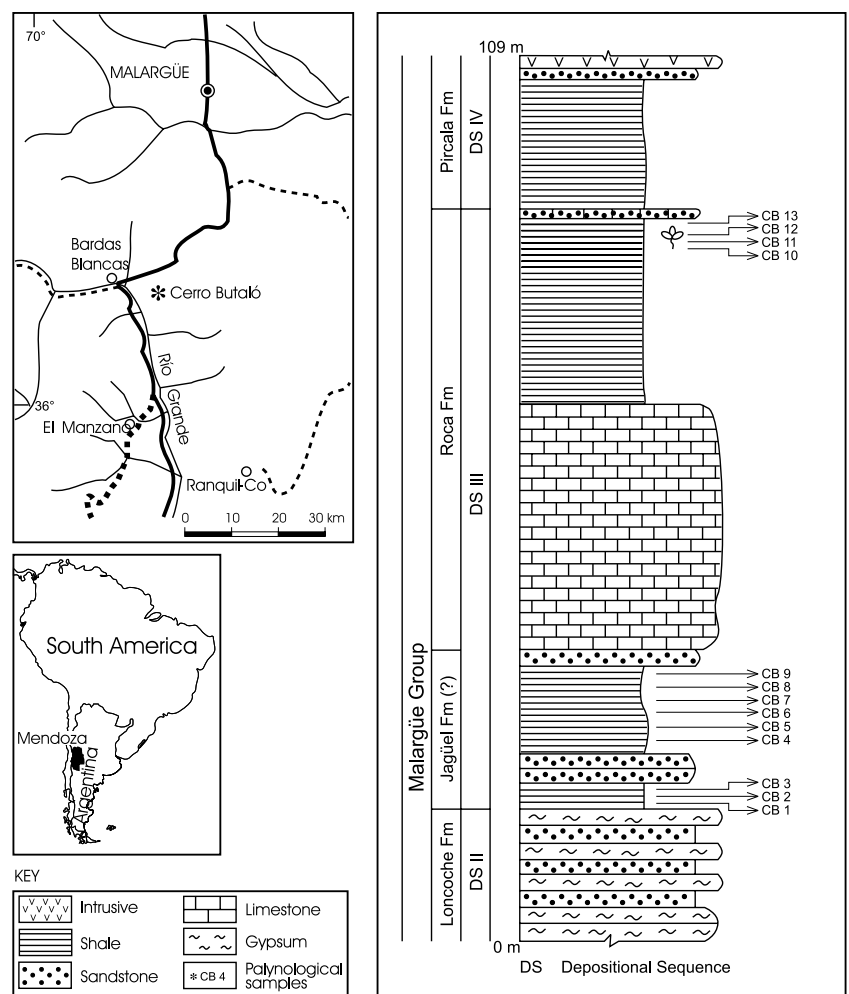

Fig. 2. Location map showing the outcrop of the Cerro Butaló section, south of Mendoza Province and the stratigraphical column of the Malargüe Group at the studied section, indicating the sampling levels.

part of the basin the $\mathrm{K}-\mathrm{T}$ boundary would lie within the continental deposits of the Pircala Formation (their depositional sequence IV). This is based on a combination of isotope age determination and palaeontological data. A ${ }^{40} \mathrm{~K}-{ }^{40} \mathrm{Ar}$ $(58.4 \pm 2.9 \mathrm{Ma})$ radiometric age was recorded from the Cerro Butaló section, from tuffs located $90 \mathrm{~m}$ above the youngest marine bed of the section. Maastrichtian bivalve species have been found within the limestone beds of the Roca Formation (i.e. Ambigostrea clarae Ihering, Amphidonte mendozana Ihering and Pterotrigonia sp.). Scarce, poorly preserved nannofossils (Arkhangelskiella cymbiformis, Micula decussata, Watznaueria barnesae and Eiffellithus sp.) and foraminifera (Quinqueloculina sp, Cibicides sp. and Guttulina sp.) occur within the lower part of the section studied (Jagüel Formation) (A. M. Parras, pers. comm.).

The aim of this paper is to report on the biostratigraphical results from the dinoflagellate cyst assemblages obtained from the $\mathrm{K}-\mathrm{T}$ boundary strata of the Cerro Butaló section. Some local dinoflagellate cyst bioevents are suggested in order to refine both the age determination of the strata and palaeoenvironmental interpretations. This is the first illustrated report of Late Cretaceous dinoflagellate cyst associations from the NNW point of the Neuquen Basin, Mendoza Province, western Argentina.

\section{MATERIAL AND METHODS}

Thirteen samples were collected from the Cerro Butaló section, nine from the Jagüel Formation and four from the Roca Formation (Figs 1 and 2). The samples were processed using standard palynological techniques involving $\mathrm{HF}$ and $\mathrm{HCl}$ treat- ment. The residues were sieved to remove fine material using $10 \mu \mathrm{m}$ nickel precision sieves, stained with safranine and finally mounted in glycerine jelly. The slides were studied using a light microscope (OLYMPUS BX50) and the photomicrographs were taken under phase and interference contrast illumination. England Finder coordinates are provided for the photographed specimens (Plates 1-4). All the material is stored in the palaeopalynological collection of the Unit of Palaeopalynology of the Argentinian Institute of Snow Research, Glaciology and Environmental Sciences (IANIGLA), CRICYT, Mendoza under the catalogue numbers CB1(5737), CB2(5738), CB3(5739), CB4(5740), CB5(5741), CB6(5742), CB7(5743), CB8(5744), CB9(5745), CB10(5746/7406), CB11(5747), CB12(5748) and CB13(5749/5864), followed by the abbreviation MPLP (Mendoza-Palaeopalinoteca-Laboratory of Palaeopalynology).

Well-preserved palynological assemblages were recovered. However, as the abundance of palynomorphs in most samples was low, only 100 or 150 specimens were counted per sample. The relative abundance (dinoflagellate cysts/terrestrial palynomorphs) is shown in Figure 3. Several taxa were represented by single occurrences in some samples, hindering taxonomic classification. Four slides per sample were scanned at about $400 \times$ under phase illumination, and the distribution of the dinoflagellate cysts and algae is shown in Table 1. Only the microplankton associations (dinoflagellate cysts, acritarchs and green algae) are discussed herein.

\section{DINOFLAGELLATE CYST DISTRIBUTION}

Over 40 dinoflagellate taxa were recognized (see the taxonomic list at the end) and their distribution was analysed from the Jagüel and Roca Formations.

\section{Jagüel Formation}

Dinoflagellate cysts dominate the lower part of the section in almost all the samples studied $(75-94 \%)$. Terrestrial palynomorphs are abundant only in CB4 (68\%) and CB5 (57\% of the assemblage). Within the Gonyaulacoid cyst group, representatives of the Spiniferites/Achomosphaera complex are the most common species in the Jagüel Formation, where they are coincident with high dinoflagellate cysts/terrestrial palynomorphs ratios. Species of GlaphyrocystalAreoligera are also abundant, particularly in samples CB3 and CB6. Hystrichosphaeridium tubiferum has its lowest occurrence in CB4 and Disphaerogena carposphaeropsis, Tityrosphaeridium tenuistriatum and Piercites pentagona have lowest occurrences in CB1 and in CB2. Peridinioid cysts belonging to the Andalusiellal Palaeocystodinium complex are also present throughout. Deflandrea galeata has its lowest occurrence in CB1. Phelodinium magnificum occurs in $\mathrm{CB} 2$ and $\mathrm{CB} 7$ and Lejeunecysta granosa is only present in CB7; both are the most important species within the Protoperidiniaceae.

Freshwater algae (Pediastrum and Botryococcus) and marine algae (Palambages morulosa and Pterospermella australiense) occur in relatively low numbers, but are present in several samples (Table 1).

\section{Roca Formation}

A major change in the dinoflagellate cysts association was observed between the Roca and Jagüel Formations, with 

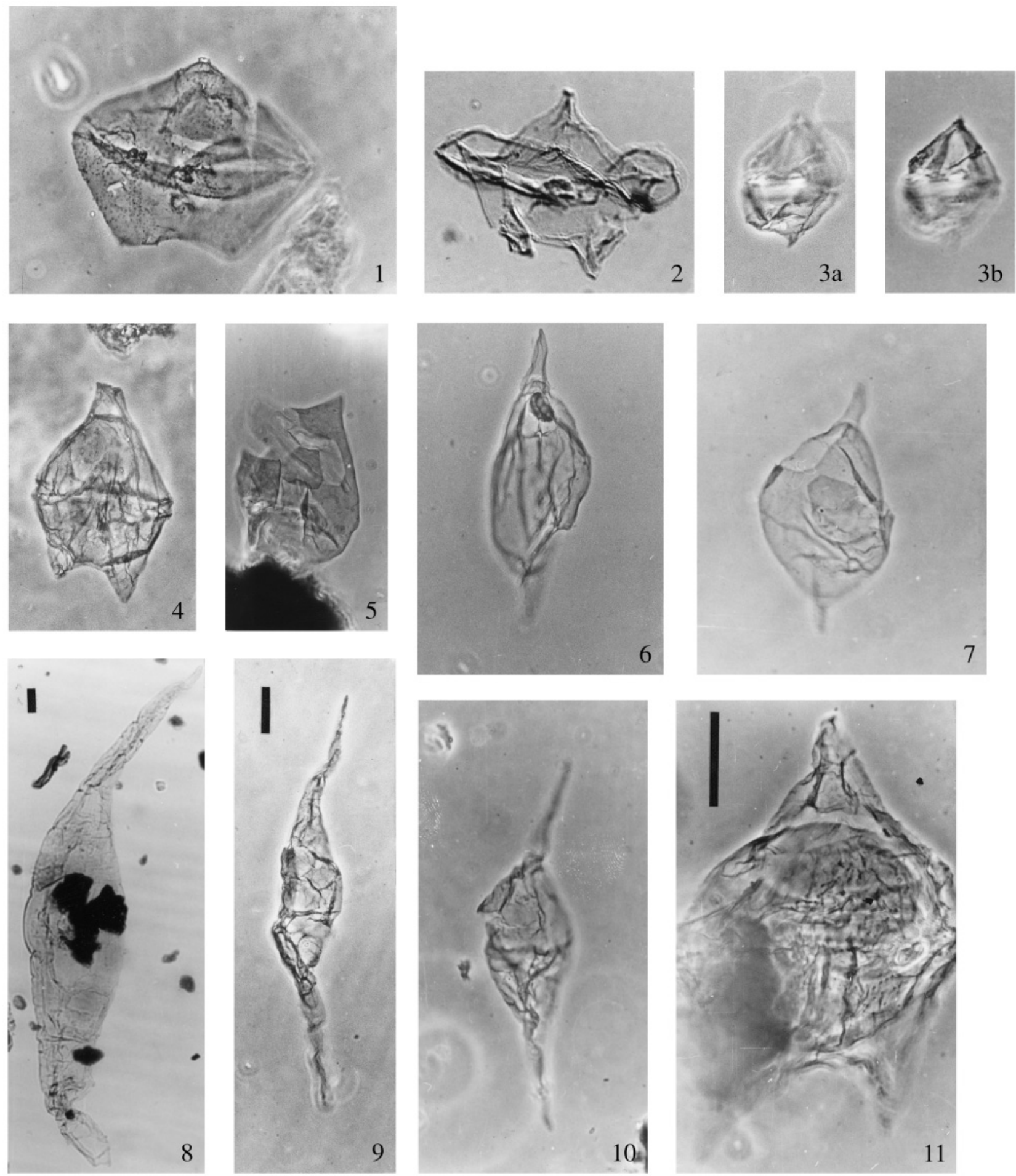

Explanation of Plate 1.

Dinoflagellate cysts from the Jagüel Formation, Cerro Butaló section. All figures were taken under phase contrast illumination, except figure 2 which was taken under interference contrast illumination. All figures correspond to the same magnification $(400 \times)$, except figures $8(200 \times)$ and $11(800 \times)$. Scale bars equal $20 \mu \mathrm{m}$. fig. 1. Lejeunecysta granosa, CB7d: L18/0, dorsal view, dorsal surface. fig. 2. Phelodinium magnificum, CB2a: X37/3, high focus. figs 3a \& b. Laciniadinium arcticum, CB6c: L28/2 - (a) low focus, view of the oblique antapical spine; (b) high focus. fig. 4. Cerodinium cf. pannuceum, CB3b: M23/3, ventral view, dorsal surface; specimen with short antapical horns. fig. 5. Piercites pentagona, CB2a: L34/4, ventral view, dorsal surface, archaeopyle with one of the opercular pieces (2a) in place. fig. 6. Andalusiella sp. CB2a: P28/1, ventral view, dorsal surface. fig. 7. Andalusiella mauthei, CB2c: U32/0, right lateral view. fig. 8. Palaeocystodinium australinum, CB0b: X36/4, high focus, very large specimen of $340 \mu$ m. fig. 9. Palaeocystodinium golzowense, CB2d: X41/3, high focus. fig. 10. Palaeocystodinium lidiae, CB3c: U38/1, right lateral view. fig. 11. Deflandrea galeata, CB2: W42/3, dorsal view, dorsal surface, $100 \mu \mathrm{m}$ high. 

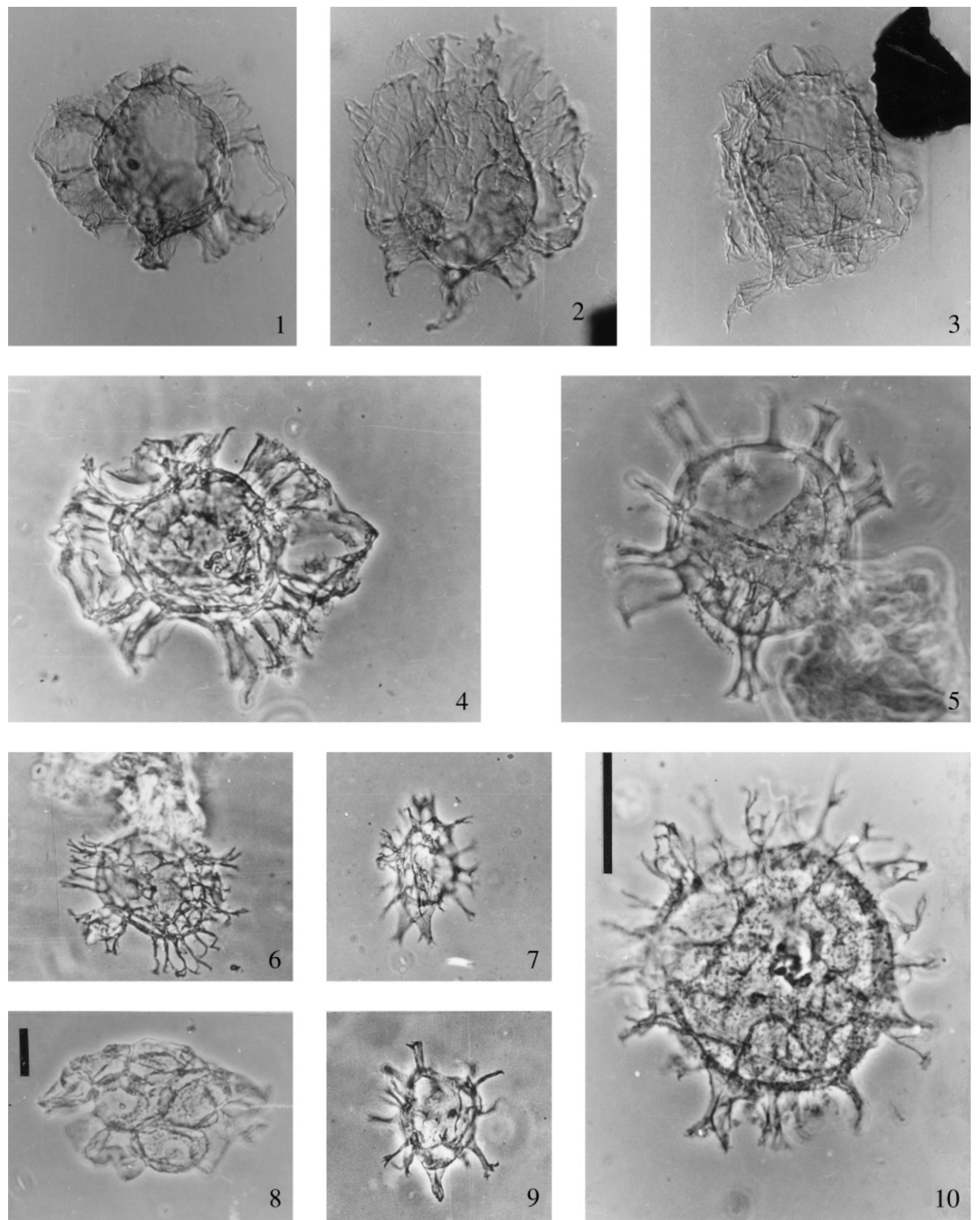

Explanation of Plate 2.

Dinoflagellate cysts from the Jagüel Formation, Cerro Butalo section. All figures correspond to the same magnification $(400 \times)$ except figure 10 $(1000 \times)$; all were taken under phase contrast illumination except figures 2 and 3, which were taken under interference contrast illumination. Scale bars equal $20 \mu \mathrm{m}$. figs 1-4. Disphaerogena carposphaeropsis: 1, CB3a: O38/3, ventral view, ventral surface; 2, CB5c: R31/1, dorsal view, dorsal surface; 3, CB5b: V39/3, dorsal view, dorsal surface, specimen with long developed antapical horn; 4, CB3c: S37/0, ventral view, ventral surface. fig. 5. Tityrosphaeridium tenuistriatum, CB3c: Q24/4, ventral view, dorsal surface. fig. 6 AchomosphaeralSpiniferites group, CB6b: K31/1, intermediate focus. fig. 7. Spiniferites ramosus, CB3b: K22/1, intermediate focus. fig. 8. Palambages morulosa, CB5c: Q24/2, high focus. fig. 9. Florentinia sp., CB2c: D40/4, low focus. fig. 10. Spiniferites ramosus group, CB3a: V40/3, intermediate focus, body ornamented with coni and baculae. 

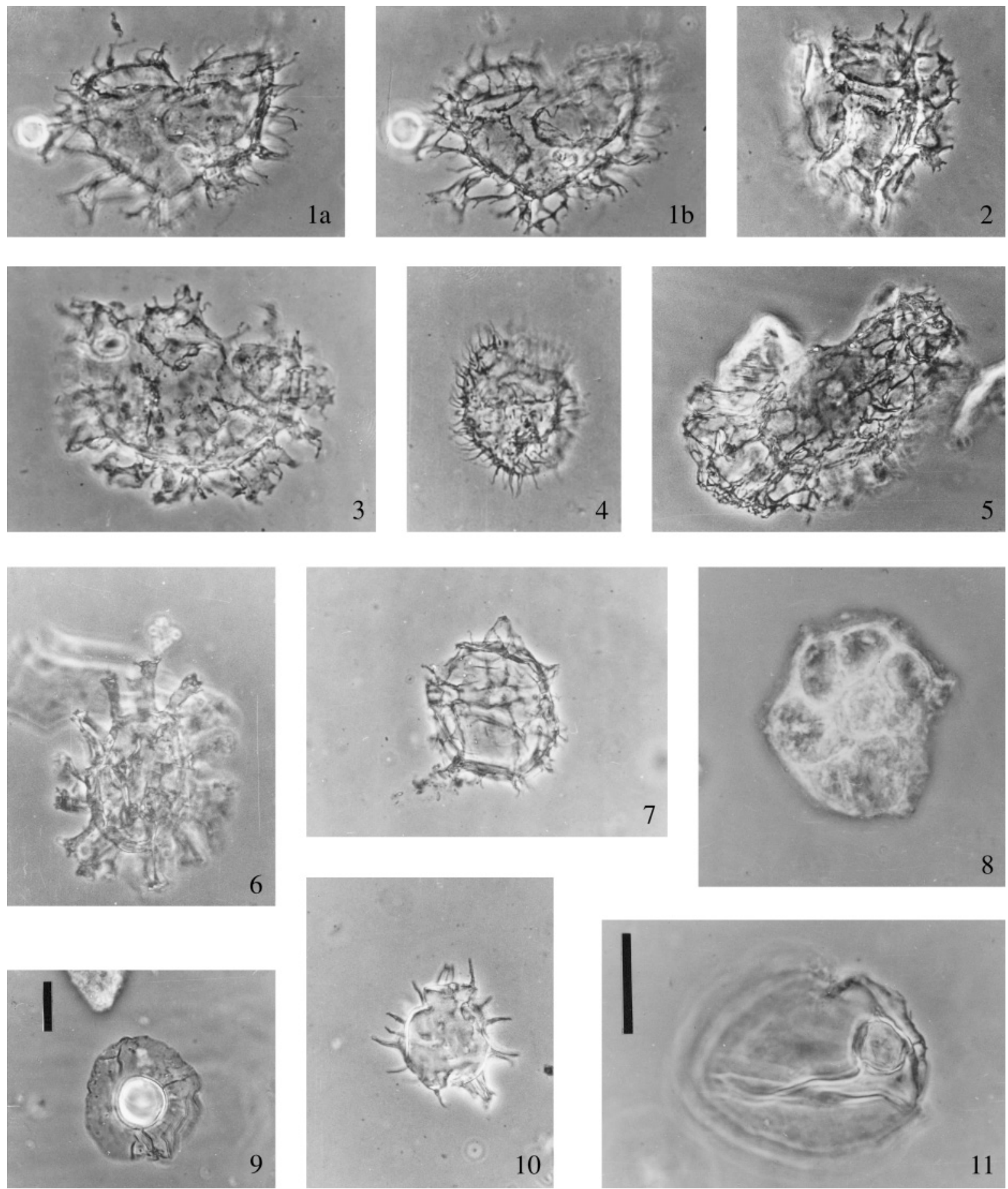

Explanation of Plate 3.

Marine palynomorphs from the Jagüel Formation except figure 10 which belongs to the Roca Formation. All figures correspond to the same magnification $400 \times$, except figure $11(800 \times)$. Taken under phase contrast illumination. Scale bars equal $20 \mu \mathrm{m}$. figs $\mathbf{1}$ a-b. Areoligera medusettiformis, CB3c: M22/3 - (a) dorsal view, ventral surface; (b) dorsal view, dorsal surface. fig. 2. Areoligera cf. tauloma, CB3a: O27/4, mid focus. fig. 3. Areoligera coronata, CB3a: R28/1, dorsal view, dorsal surface. fig. 4. Cleistosphaeridium? cf. aciculare, CB3c: K25/0, high focus. fig. 5. Glaphyrocysta retiintexta, CB6b: U24/1, high focus. fig. 6. Hystrichosphaeridium tubiferum, CB7d: M38/1, high focus. fig. 7. Spiniferites ramosus group, CB9a: C27/3. fig. 8. Foraminifer lining, CB9b: O28/0. fig. 9. Pterospermella australiense, CB6c: R42/1, high focus. fig. 10. Acritarch indet., CB10a: W38/0, intermediate focus. fig. 11. Cyclopsiella sp., CB3b: K40/1. 

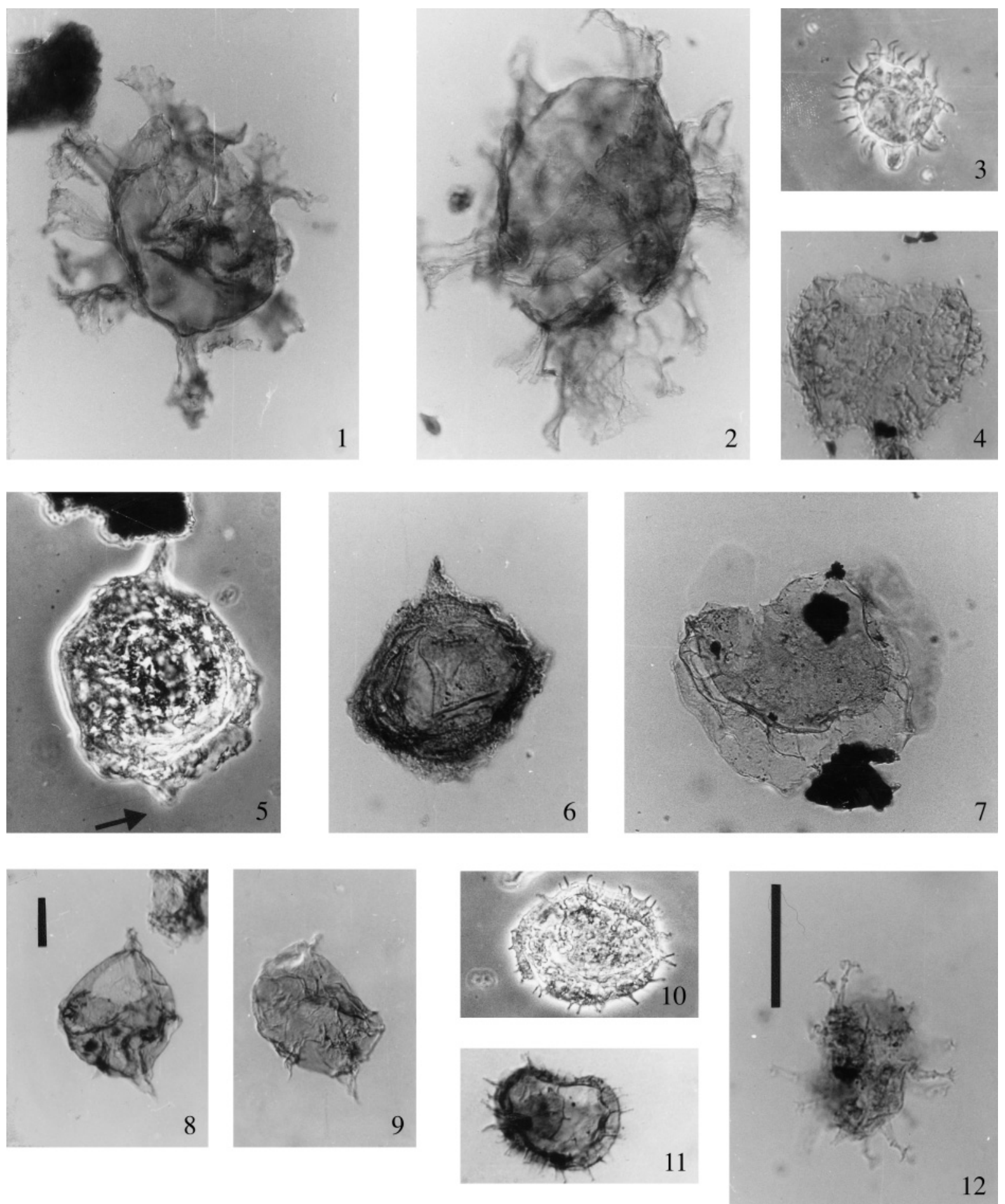


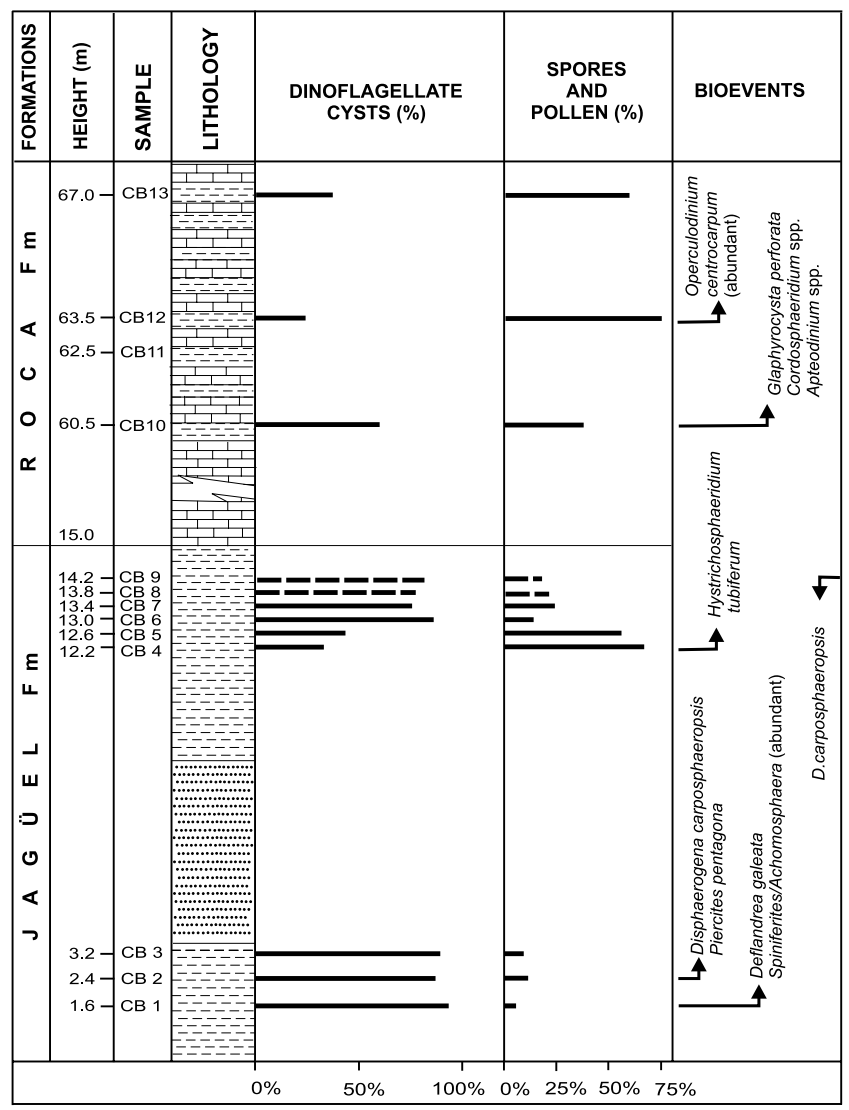

СВ 3 Palynological sample $\mathbf{4}$ First appearance datum (FAD)
$\mp$ Last appearance datum (LAD)

Fig. 3. Relative abundance of dinoflagellate cysts/terrestrial palynomorphs (spores and pollen grains) and suggested local dinoflagellate cyst bioevents based on the first (FAD) and last (LAD) appearance of some selected taxa in the Cerro Butaló section. The dashed lines at samples $\mathrm{CB} 8$ and $\mathrm{CB} 9$ indicate a statistical result calculated from a count of less than 100 specimens.

virtually no common species between the formations. Marine microplankton are dominant only in sample CB10 $(61 \%$ of the palynomorph assemblage), in which members of the Cordosphaeridium/Fibrocysta complex are abundant, in association with Apteodinium cf. australiense, ?Diphyes colligerum, Glaphyrocysta perforata, Circulodinium distinctum and Senegalinium bicavatum. At the top of the Cerro Butaló section (CB12, CB13), a decrease in microplankton diversity and abundance (only $26 \%$ are dinoflagellate cysts in CB12 and $38 \%$ in CB13) and an increase in the dominance of Operculodinium centrocarpum is observed. This species appears high in the section at $\mathrm{CB} 10$ and becomes dominant in $\mathrm{CB} 12$ and $\mathrm{CB} 13$, where it is associated with a sharp increase in the relative abundance of structured plant debris, wood fragments and algal debris.

\section{BIOSTRATIGRAPHY}

There are only a few published dinoflagellate cyst studies on the $\mathrm{K}-\mathrm{T}$ boundary in Argentina and southern South America (Colorado Basin: Gamerro \& Archangelsky, 1981; Quattrocchio \& Sarjeant, 1996; Guerstein \& Junciel, 2001; Neuquén Basin:
Papú et al., 1999; Palamarczuk \& Habib, 2001; Palamarczuk, 2002; Austral Basin: Martinioni et al., 1999; Guler et al., 2003; Brasil, Campos Basin and Pernambuco Basin: Arai, 1994, Sarkis et al., 2002; Punta del Este Basin: Daners \& Guerstein, 2004). Most of these contributions are only abstracts, and so comparisons have been made with selected dinoflagellate cyst species ranges from outside South America in order to determine the age of the strata. Some important dinoflagellate cyst bioevents, based on selected first appearance datum (FAD), abundance and last appearance datums (LAD) of selected dinoflagellate cyst species are illustrated in Figure 3.

Deflandrea galeata has its first occurrence in the middle late Maastrichtian of the Danish part of the North Sea, Dan Field (Schiøler \& Wilson, 1993); Maastricht Formation, Borehole Bunde in The Netherlands (Herngreen et al., 1986) and onshore west Greenland (Nøhr-Hansen, 1996). In Argentina, it has been recorded in the Late Maastrichtian of the Jagüel Formation in two sections located in Neuquen Province, to the southeast of the Cerro Butaló section (Papú et al., 1999; Palamarczuk, 2002). In the Cerro Butaló section the FAD of Deflandrea galeata is in CB1.

Disphaerogena carposphaeropsis (taxonomic junior synonym: Cyclapophysis monmouthensis Benson) is a useful Late Maastrichtian world-wide marker and its distribution in various $\mathrm{K}-\mathrm{T}$ boundary localities is well documented (e.g. Benson, 1976; Firth, 1987; Brinkhuis \& Leereveld, 1988; Brinkhuis \& Schiøler, 1996). In northern South America, Yepes (2001) reported its occurrence in the upper part of the Maastrichtian. In the South Atlantic (Brazil) it has been found in the Campos Basin (Arai, 1994) in the uppermost Maastrichtian and also in the $\mathrm{K}-\mathrm{T}$ boundary section of Pernambuco Basin (Sarkis et al., 2002). In Argentina, D. carposphaeropsis has been reported from the Jagüel Formation in the east of the Neuquén Basin, including the Opaso (Papú et al., 1999) and Jagüel (type section) sections (Palamarczuk \& Habib, 2001), where Late Maastrichtian ages have been assigned. Recently, Williams et al. (2004) published for the first time a detailed Southern Ocean calibration of dinoflagellate cyst events, based on studies of two Ocean Drilling Project (ODP) sites offshore Tasmania; they indicated the FAD of $D$. carposphaeropsis at $67 \mathrm{Ma}$. In the studied section $D$. carposphaeropsis has its FAD in CB1 and its LAD in CB6. This species was not recorded in the upper part of the section in the Roca Formation, probably due to changes in environmental conditions.

Glaphyrocysta perforata is also a good marker for the uppermost Maastrichtian and occurs in CB10. It was reported by Schiøler et al. (1996) in the ENCI Quarry, Upper Maastrichtian Gulpen Formation, The Netherlands and by Yepes (2001) immediately below the $\mathrm{K}-\mathrm{T}$ boundary in Rio Loro section, western Venezuela (northern South America).

One taxonomic feature of the biostratigraphical analysis is the development of distinct apical and antapical horns in specimens of D. carposphaeropsis (P1. 2, figs 2-4) and Cordosphaeridium sp. (Pl. 4, figs 1, 2) in both the Jagüel and Roca Formations. This is a typical feature of forms in the Disphaerogena-Cordosphaeridium-Damassadinium-ThalassiphoraCarpatella-Fibrocysta complex close to, and above, the K-T boundary (Brinkhuis \& Schiøler, 1996; Herngreen et al., 1998). Some of the specimens assigned to Apteodinium cf. australiense 
M. B. Prámparo \& O. H. Papú

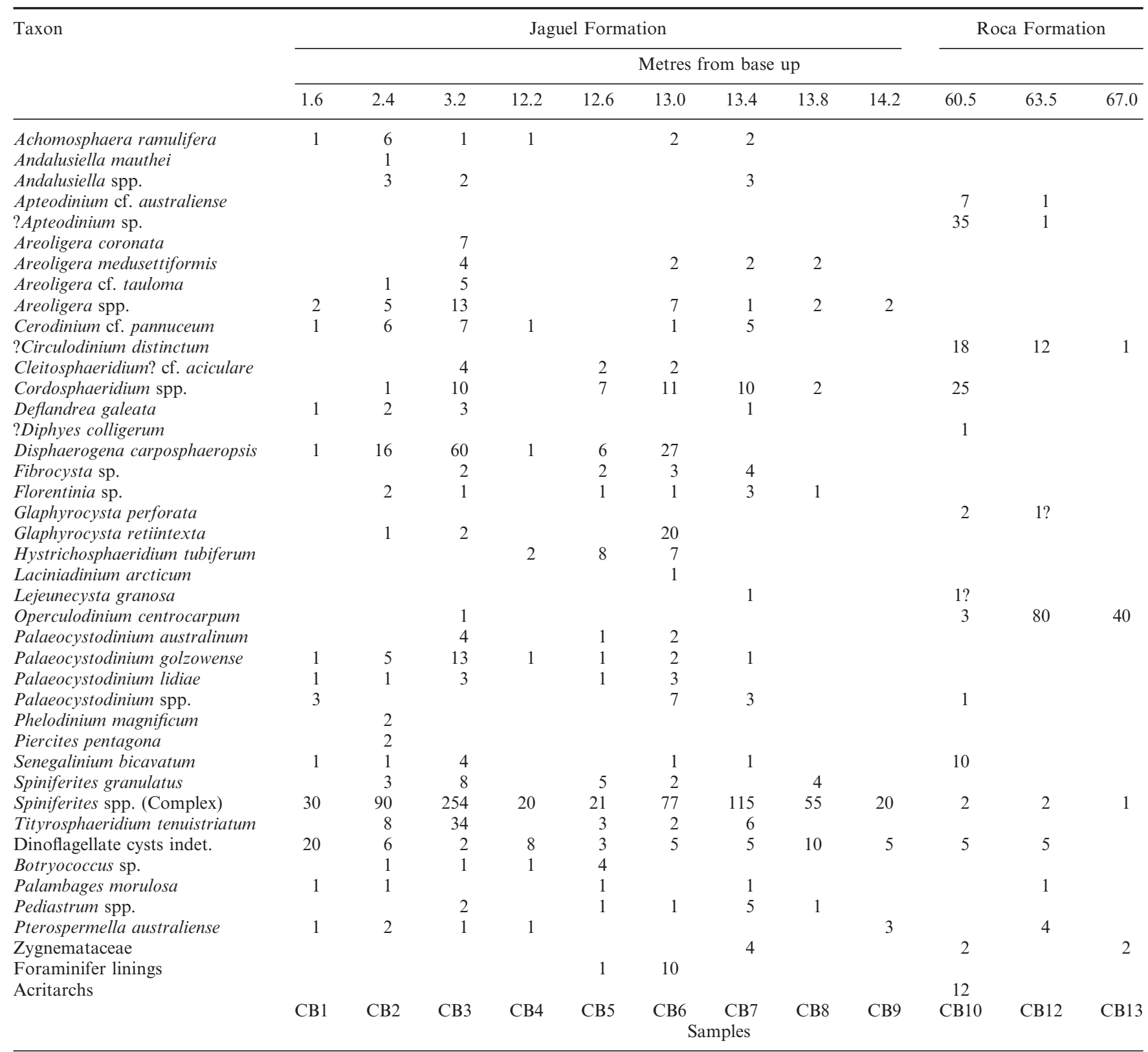

Table 1. Dinoflagellate cyst distribution range chart (samples CB1 to CB9) Jagüel Formation and (CB10 to CB13) Roca Formation at the Cerro Butaló section, south of Mendoza Province, NNW of Neuquén Basin

(P1. 4, fig. 5) may also be transitional forms within the Carpatella cornuta complex, based on the presence of an incipient antapical horn. This feature may be elucidated by further study and comparison of more specimens in the future, obtained from other sections of the basin. Representatives of Dinogymnium do not occur in the studied association, whereas this genus was mentioned for the Jagüel Formation in the Lomas Coloradas section of the Neuquen Basin (Palamarczuk, 2002).

Palamarczuk \& Habib (2001) reported that the K-T boundary interval occurred within the Jagüel Formation in the Jagüel section (type section) of Neuquen Province ( $38^{\circ} 06^{\prime} 25^{\prime \prime} \mathrm{S}$, $\left.68^{\circ} 23^{\prime} 36^{\prime \prime} \mathrm{W}\right)$. This was based on the presence of $D$. carposphaeropsis, indicative of the latest Maastrichtian, and
Senoniasphaera inornata which occurs at the earliest Danian. They also reported a peak abundance of Manumiella druggii, just below the $\mathrm{K}-\mathrm{T}$ boundary but it was not observed in the Cerro Butaló section. In Australia, M. druggii is a good marker for the Late Maastrichtian to earliest Danian Manumiella druggii Interval Zone (Helby et al., 1987), just below the K-T boundary. However, it was not observed at the Cerro Butaló section.

In summary, the occurrence in the lower part of the section studied of Deflandrea galeata and Disphaerogena carposphaeropsis and Glaphyrocysta perforata in the upper part of the section associated with an absence of any unequivocal Danian markers (e.g. Danea californica, Carpatella cornuta or Senonia- 
sphaera inornata) is interpreted as being indicative of a latest Maastrichtian age for the Jagüel and Roca Formations in the Cerro Butaló section.

\section{PALAEOENVIRONMENTAL INTERPRETATION}

Throughout the Cerro Butaló section, dinoflagellate cyst species diversity variation was observed which allowed the recognition of two main intervals, probably related to palaeoenvironmental conditions. This may be connected with episodes of sea-level fluctuations, related to the existence of a narrow and shallow seaway (Legarreta et al., 1989). The first interval (CB1 to CB9) (Fig. 3) corresponds to the Jagüel Formation and is dominated by representatives of the complex Spiniferites/Achomospharera, whilst specimens of Glaphyrocysta/Areoligera were subordinate. Spiniferites/Achomospharera are cosmopolitan neritic genera (Head \& Westphal, 1999). Yepes (2001), after a discussion about the environmental conditions indicated by the Spiniferites/ Achomosphaera group, concluded that environmental interpretations are still incomplete, as they could suggest a range of inner to outer neritic conditions. Based on the analysis of the situation of Cerro Butalo section in the basin, the high number of Spiniferites (Table 1) in coincidence with a high ratio of dinoflagellate cysts/terrestrial palynomorphs (Fig. 3) in nearly all the samples (CB1, 2, 3, 6, 7, 8, 9), and a high dinoflagellate cyst diversity associated with the presence of foraminifer linings, indicates a more marine influence for the lower part of the Cerro Butaló section when compared with the upper part.

The second interval, covering $\mathrm{CB} 10$ to $\mathrm{CB} 13$, corresponding to the Roca Formation, is characterized by low diversity and numbers of dinoflagellate cysts when compared with the massulae of aquatic ferns, plant tissues, algal remains and a high dominance of Operculodinium centrocarpum. Head (1998) considered a high abundance of the $O$. centrocarpum/israelianum group to be indicative of shallow waters. Therefore, a relative nearshore environment with increasingly shallower conditions is considered for the upper part of the Cerro Butaló section. This overall interpretation is supported by the regional and sedimentological results, Legarreta et al. (1989) proposed that the maximum expansion of the area under marine influence was reached during the deposition of the Jagüel Formation. After that episode, the areal extent of the region under marine influence became smaller and retracted to the southeast of the basin.

\section{ACKNOWLEDGEMENTS}

The authors thank Dr W. Volkheimer for critically reading an earlier version of the manuscript. Dr Leslie A. Riley (England) made useful suggestions on the manuscript and improved the English of the text. The authors are indebted to Drs J. Riding and F. John Gregory for their helpful suggestions which improved the final presentation of the paper. This work was supported by the National Research Council of Argentina (CONICET), Project 4674/96 and 02905/2000.

\section{LIST OF DINOFLAGELLATE CYSTS, ACRITARCHS AND GREEN ALGAE FROM THE JAGÜEL AND ROCA FORMATIONS}

Dinoflagellate cysts from the Jagüel and Roca formations are listed alphabetically by genera. Acritarchs and green algae are listed below. Illustrated taxa are followed by plate and figure references in brackets. Systematic classification follows Fensome et al. (1993) and the taxa listed are referenced fully by Williams et al. (1998).

\section{Dinoflagellate cysts}

Achomosphaera ramulifera (Deflandre) Evitt, 1963

Andalusiella mauthei (Riegel) Riegel \& Sarjeant, 1982 (Pl. 1, fig. 7)

Andalusiella spp.

Apteodinium cf. australiense (Deflandre \& Cookson, 1955)

Williams, 1978 (Pl. 4, figs 5, 6)

?Apteodinium sp.

Areoligera coronata (Wetzel, 1933b) Lejeune-Carpentier, 1938 (P1. 3, fig. 3)

Areoligera medusettiformis (Wetzel, 1933b) Lejeune-Carpentier, 1938 (P1. 3, figs 1a, b)

Areoligera cf. tauloma Eaton, 1976 (Pl. 3, fig. 2)

Areoligera spp.

Cerodinium cf. pannuceum (Stanley) Lentin \& Williams, 1987 (P1. 1, fig. 4)

?Circulodinium distinctum (Deflandre \& Cookson) Jansonius, 1986 (Pl. 4, fig. 4)

Cleitosphaeridium? cf. aciculare Davey, 1969a (Pl. 3, fig. 4)

Cordosphaeridium spp. (Pl. 4, figs 1, 2)

Deflandrea galeata (Lejeune-Carpentier, 1942) Lentin \& Williams, 1973 (Pl. 1, fig. 11)

?Diphyes colligerum (Deflandre \& Cookson, 1955) Cookson, 1965 (P1. 4, fig. 3)

Disphaerogena carposphaeropsis (Wetzel, 1933b) Sarjeant, 1985

(P1. 2, figs 1-4)

Fibrocysta $\mathrm{sp}$.

Florentinia sp. (Pl. 2, fig. 9)

Glaphyrocysta perforata Hultberg \& Malmgren, 1985 (Pl. 4, fig. 7)

Glaphyrocysta retiintexta (Cookson, 1965a) Stover \& Evitt, 1978 (P1. 3, fig. 5)

Hystrichokolpoma $\mathrm{sp}$

Hystrichosphaeridium tubiferum (Ehrenberg) Deflandre emend.

Davey \& Williams, 1966 (Pl. 3, fig. 6)

Laciniadinium arcticum (Manun \& Cookson) Lentin \& Williams, 1980 (P1. 1, figs 3a, b)

Lejeunecysta granosa Biffi \& Grignani, 1983 (Pl. 1, fig. 1)

Operculodinium centrocarpum (Deflandre \& Cookson, 1955) Wall, 1967 (Pl. 4, figs 10, 11)

Palaeocystodinium australinum (Cookson, 1965) Lentin \& Williams, 1976 (P1. 1, fig. 8)

Palaeocystodinium golzowense Alberti, 1961 (Pl. 1, fig. 9)

Palaeocystodinium lidiae (Gorka, 1963) Davey, 1969b (Pl. 1, fig. 10)

Phelodinium magnificum (Stanley, 1965) Stover \& Evitt, 1978 (P1. 1, fig. 2)

Piercites pentagona (May, 1980) Habib \& Drugg, 1987 (Pl. 1, fig. 5)

Senegalinium bicavatum Jain \& Millepied, 1973 (Pl. 4, figs 8, 9)

Spiniferites granulatus (Davey) Lentin \& Williams, 1973

Spiniferites ramosus ramosus (Ehrenberg) Mantell 1854 (Pl. 2, figs 7,10$)$

Spiniferites spp. (complex) (Pl. 2, fig. 6; Pl. 3, fig. 7) 
Tityrosphaeridium tenuistriatum (Heisecke, 1970) Quattrocchio \& Sarjeant, 1996 (Pl. 2, fig. 5)

\section{Acritarchs and algae}

Acritarch gen. et sp. indet. 1 (Pl. 3, fig. 10)

Acritarch gen. et sp. indet. 2 (Pl. 4, fig. 12)

Botryococcus sp.

Cyclopsiella sp. (Pl. 3, fig. 11)

Palambages morulosa Wetzel emend. Gocht \& Wille, 1972 (Pl. 2, fig. 8)

Pediastrum spp.

Pterospermella australiense (Deflandre \& Cookson) Eisenack, 1972 (Pl. 3, fig. 9)

Pterosphaeridia sp.

Zygnemataceae

\section{Manuscript received 7 April 2003 \\ Manuscript accepted 17 June 2005}

\section{REFERENCES}

Alberti, G. 1961. Zur Kenntnis mesozoischer und alttertertiärer Dinoflagellaten und Hystrichosphaeridium von Nord- und Mitteldeutschland sowie einigen anderen europäischen Gebieten. Palaeontographica, Abteiulung A, 116: 1-58.

Arai, M. 1994. Dinoflagelados do Cretaceo Superior (TuronianoMaastrichtiano) da Bacia de Campos, Plataforma continental do sudeste brasileiro. In: Dias-Brito, D., Ponte, F., De Castro, J., Perinotto, J.A. \& Bertini, R.J. (Eds), $3^{\circ}$ Simposio sobre o Cretáceo do Brasil, Rio Claro. Sao Paulo - UNESP - Departmento de Geología Sedimentar, 59-61.

Benson, D.G. Jr 1976. Dinoflagellate taxonomy and biostratigraphy at the Cretaceous-Tertiary boundary, Round Bay, Maryland. Tulane Studies in Geology and Paleontology, 12 (4): 169-233.

Biffi, U. \& Grignani, D. 1983. Peridinioid dinoflagellate cysts from the Oligocene of the Niger Delta, Nigeria. Micropaleontology, 29 (2): 126-145.

Brinkhuis, H. \& Leereveld, H. 1988. Dinoflagellate cysts from Cretaceous/Tertiary Boundary sequence of El Kef, Northwest Tunisia. Review of Palaeobotany and Palynology, 56: 5-19.

Brinkhuis, H. \& Schiøler, P. 1996. Palynology of the Geulhemmerberg Cretaceous/Tertiary boundary section (Limburg, SE Netherlands). Geologie en Mijnbouw, 75: 193-213.

Cookson, I.C. 1965. Microplankton from the Paleocene Pebble Point Formation, south western Victoria. Proceedings of the Royal Society of Victoria, 78: 137-141.

Daners, G. \& Guerstein, R. 2004. Dinoflagelados del MaastrichtiensePaleógeno de la Formación Gaviotín, Cuenca de Punta del Este. In: Veroslasvsky, G., Ubilla, M. \& Martinez, S. (Eds), Cuencas sedimentarias de Uruguay-Cenozoico, 2. DIRAC, Facultad de Ciencias, 37-62.

Davey, R.J. 1969a. Non-calcareous microplankton from the Cenomanian of England, northern France and North America, Part I. British Museum (Natural History) Geology, Bulletin, 17: 103-180.

Davey, R.J. 1969b. Some dinoflagellate cysts from the Upper Cretaceous of Northern Natal, South Africa. Palaeontologia Africana, 12: 1-23.

Davey, R.J. \& Williams, G.L. 1966. The genus Hystrichosphaeridium and its allies. In: Davey, R.J., Downie, C., Sarjeant, W.A.S. \& Williams, G.L. (Eds), Studies on Mesozoic and Cainozoic dinoflagellate cysts. British Museum (Natural History) Geology, Bulletin, Supplement, 3: 53-106.

Deflandre, G. \& Cookson, I.C. 1955. Fossil microplankton from Australian Late Mesozoic and Tertiary sediments. Australian Journal of Marine and Freshwater Research, 6: 242-313.

Eaton, G.L. 1976. Dinoflagellate cysts from the Bracklesham Beds (Eocene) of the Isle of Wight, southern England. British Museum (Natural History) Geology, Bulletin, 26: 227-332.

Eisenack, A. 1972. Kritische Bemerkung zur Gattung Pterospermopsis (Clorophyta, Prasinophyceae). Critical remarks about Ptero- spermopsis. Neues Jahrbuch für Geologie und Paläontologie, 10: 596-601.

Evitt, W.R. 1963. A discussion and proposal concerning fossil dinoflagellates, hystrichospheres, and acritarchs, I. National Academy of Sciences, Washington, Proceedings, 49: 158-164.

Fensome, R.A., Taylor, F.J.R., Norris, G., Sarjeant, W.A.S., Wharton, D.I. \& Williams, G.L. 1993. A classification of fossil and living dinoflagellates. Micropaleontology Press Special Paper, 7: 351pp.

Firth, J.V. 1987. Dinoflagellate biostratigraphy of the Maastrichtian to Danian interval in the U.S. Geological Survey Albany Core, Georgia, U.S.A. Palynology, 11: 199-216.

Gamerro, J.C. \& Archangelsky, S. 1981. Palinozonas neocretácicas y terciarias de la Plataforma continental Argentina en la Cuenca del Colorado. Revista Española de Micropaleontología, 13: 119-140.

Gocht, H. \& Wille, W. 1972. Untersuchungen an Palambages morulosa O.Wetzel (Chlorophyceae inc. sed.). Neues Jahrbuch für Geologie und Paläontologie, 3: 146-161.

Groeber, P. 1947. Observaciones Geológicas a lo largo del meridiano $70^{\circ}$. 4. Hojas Bardas Blancas y Los Molles. Revista de la Sociedad Geológica Argentina, 2 (4): 409-433.

Guerstein, G.R. \& Junciel, G.L. 2001. Quistes de dinoflagelados del Cenozoico de la Cuenca del Colorado, Argentina. Ameghiniana, 38 (3): 299-316.

Guler, M.V., Guerstein, G.R., Papú, O.H., Casadio, S. \& Maranessi, S. 2003. Palinomorfos del Maastrichtiano de la Formación Calafate, sudoeste de Santa Cruz, Argentina. Ameghiniana, Suplemento (resúmenes), 40 (4): 88.

Habib, D. \& Drugg, W.S. 1987. Palynology of Sites 603 and 605, Leg 93, Deep Sea Drilling Project. In: Blakeslee, J.H., Whalen, E. (Eds), Deep Sea Drilling Project, Washington, Initial Reports, 93(2): 751-775.

Head, M. 1998. Marine environmental change in the Pliocene and early Pleistocene of eastern England: the dinoflagellate evidence reviewed. In: Van Kolfshoten, T. \& Gibbard, P. (Eds), The Dawn of the Quaternary. Mededelingen Nederlands Instituut voor Toegepaste Geowetenschappen TNO, 60: 119-225.

Head, M.J. \& Westphal, H. 1999. Palynology and palaeoenvironments of a Pliocene carbonate platform: The Clino core, Bahamas. Journal of Paleontology, 73 (1): 1-25.

Heisecke, A.M. 1970. Microplancton de la Formación Roca de la Provincia de Neuquén. Ameghiniana, 7 (3): 225-263.

Helby, R., Morgan, R. \& Partridge, A.D. 1987. A palynological zonation of the Australian Mesozoic. Memoir of the Association of Australasian Palaeontologists, 4: 1-94.

Herngreen, G.F.W., Felder, W.M., Kedves, M. \& Meessen, J.P.M.T. 1986. Micropaleontology of the Maestrichtian in Borehole Bunde, The Netherlands. Review of Palaeobotany and Palynology, 48: 1-70.

Herngreen, G.F.W., Schuurman, H.A.H.M., Verbeek, J.W., Brinkhuis, H., Burnett, J.A., Felder, W.M. \& Kedves, M. 1998. Biostratigraphy of Cretaceous/Tertiary boundary strata in the Curfs quarry, The Netherlands. Mededelingen Netherlands Institute of Applied Geoscience TNO, 61: 1-58.

Hultberg, S.U. \& Malmgren, B.A. 1985. Quantitative biostratigraphy based on Upper Maastrichtian dinoflagellates and planktonic foraminifera from southern Scandinavia. In: Hultberg, S.U. (Ed.), Dinoflagellate Studies of the Upper Maastrichtian and Danian in Southern Scandinavia. Thesis. University of Stockholm, 33-55.

Jain, K.P. \& Millepied, P. 1973. Cretaceous microplankton from Senegal Basin, NW Africa, I. Some new genera, species and combinations of dinoflagellates. The Palaeobotanist, 20: 22-32.

Jansonius, J. 1986. Re-examination of Mesozoic Canadian dinoflagellate cysts published by Pocock (1962, 1972). Palynology, 10: 201-223.

Legarreta, L., Gulisano, C.A. \& Boggetti, D.A. 1989. Depositional sequences of the Malargüe Group (Upper Cretaceous-Lower Tertiary), Neuquén Basin, Argentina. Cretaceous Research, 10: 337-356.

Lejeune-Carpentier, M. 1938. L' étude microscopique des silex, Areoligera: nouveau genre d' Hystrichosphaeridée. (Sixiéme note.). Annales de la Societé géologique de Belgique, 62: B163-B174.

Lentin, J.K. \& Williams, G.L. 1973. Fossil dinoflagellates: index to genera and species. Geological Survey of Canada, Paper, 73-42: $176 \mathrm{pp}$. 
Lentin, J.K. \& Williams, G.L. 1976. A monograph of fossil peridinioid dinoflagellate cysts. Bedford Institute of Oceanography, Report Series, B1-R-75-16: 237pp.

Lentin, J.K. \& Williams, G.L. 1980. Dinoflagellate provincialism with emphasis on Campanian peridiniaceans. American Association of Stratigraphic Palynologists, Contribution Series, 7: 47pp.

Lentin, J.K. \& Williams, G.L. 1987. Status of the fossil dinoflagellate genera Ceratiopsis Vozzhennikova 1963 emend. Palynology, 11: $113-116$.

Mantell, G.A. 1854. The Medals of Creation or First Lessons in Geology and the Study of Organic remains 2nd edn. Henry G. Bohn (Ed), London, 930pp.

Martinioni, D.R., Olivero, E.B. \& Palamarczuk, S. 1999. Estratigrafía y discordancias del Cretácico Superior-Paleoceno en la región central de Tierra del Fuego. In: Nañez, C. (Ed.), Simposio Paleogeno de América del Sur. Actas Subsecretaria de Minería de la Nación, Servicio Geológico Minero Argentino, Anales, 33: 7-16.

Nøhr-Hansen, H. 1996. Upper Cretaceous dinoflagellate cyst stratigraphy, onshore West Greenland. Gronlands Geologiske Undersiogelse Bulletin, 170: 1-104.

Palamarczuk, S. 2002. Maastrichtian dinoflagellates from the Jagüe Formation, Neuquén Province, Argentina (abstract). Palynology, 26: 272.

Palamarczuk, S. \& Habib, D. 2001. Dinoflagellate evidence of the Cretaceous-Paleogene Boundary in Argentina (abstract). GSA Annual Meeting, Abstract: $27662 \mathrm{htm}$.

Papú, O.H., Prámparo, M.B., Nañez, C. \& Concheyro, A. 1999. Palinología y micropaleontología de la Formación Jagüel (Maastrichtiano-Daniano), Perfil Opaso, cuenca Neuquina, Argentina. In: Nañez, C. (Ed.), Simposio Paleogeno de América del Sur. Actas Subsecretaria de Minería de la Nación, Servicio Geológico Minero Argentino, Anales, 33: 17-31.

Parras, A.M., Casadío, S. \& Pires, W. 1998. Secuencias depositacionales del Grupo Malargüe y el Límite Cretácico-Paleógeno, en el Sur de la Provincia de Mendoza, Argentina. In: Casadío, S. (Ed.), Paleógeno de América del Sur y de la Península Antártica. Asociación Paleontológica Argentina, Publicación Especial, 5: 61-69.

Quattrocchio, M.E. \& Sarjeant, W.A.G. 1996. Early Paleogene (Danian) dinoflagellates from the Colorado Basin, Argentina. Revista Española de Micropaleontología, 28 (3): 111-138.

Riegel, W. \& Sarjeant, W.A.S. 1982. Dinoflagellate cysts from the upper Cretaceous of southern Spain: new morphological and taxonomic observations. Neues Jahrbuch für Geologie und Paläontologie, 162: 286-303
Sarjeant, W.A.S. 1985. A restudy of some dinoflagellate cyst holotypes in the University of Kiel collections: IV. Late Cretaceous dinoflagellate cysts and other palynomorphs in the Otto Wetzel collection. Meyniana, 37: 129-185.

Sarkis, M.F.R., Arai, M. \& Koutsoukos, E.A.M. 2002. Dinoflagelados do limite Cretáceo-Terciario (K-T), Pedreira Poty, Bacia de Pernambuco-Paraíba, Nordeste do Brasil. In: De Castro, J.C., Dias-Brito, D., Musacchio, E.A. \& Rohn, R. (Eds), Boletim do $6^{\circ}$ Simposio sobre o Cretáceo do Brasil y 2 do Simposio sobre el Cretácico de América del Sur, Sao Pedro. Sao Paulo - UNESP - Instituto de Geosciencias e Ciencias Exatas, 271-277.

Schiøler, P. \& Wilson, G.J. 1993. Maastrichtian dinoflagellate zonation in the Dan Field, Danish North Sea. Review of Palaeobotany and Palynology, 78: 321-351.

Schiøler, P., Brinkhuis, H., Roncaglia, L. \& Wilson, G. 1996. Dinoflagellate biostratigraphy and sequence stratigraphy of the Type Maastrichtian (Upper Cretaceous), ENCI Quarry, The Netherlands. Marine Micropaleontology, 31: 65-95.

Stover, L.E. \& Evitt, W.R. 1978. Analyses of pre-Pleistocene organicwalled dinoflagellates. Stanford University Publications, Geological Sciences, 15: 300pp.

Uliana, M.A. \& Dellape, D.A. 1981. Estratigrafía y evolución paleoambiental de la sucesión Maastrichtiana-eoterciaria del engolfamiento neuquino (Patagonia Septentrional). In: Nullo, F.E., Ploszkiewicz, V. \& Marin, G. (Eds), Octavo Congreso Geológico Argentino. Asociación Geológica Argentina (San Luis), Tomo, 3: 673-711.

Wall, D. 1967. Fossil microplankton in deep-sea cores from the Caribbean Sea. Palaeontology, 10 (1): 95-123.

Williams, G.L. 1978. Palynological biostratigraphy, Deep Sea Drilling Project Sites 367 and 370. In: Gardner, J., Herring, J. (Eds), Deep Sea Drilling Project, Washington, Initial Report, Supplement, 41: 783-815.

Williams, G.L., Lentin, J. \& Fensome, R.A. 1998. The Lentin and Williams Index of fossil dinoflagellates 1998 Edition. American Association of Stratigraphic Palynologists Foundation, Contribution Series, 34: 817pp.

Williams, G.L., Brinkhuis, H., Pearce, M.A., Fensome, R.A. \& Weegink, J.W. 2004. Southern Ocean and global dinoflagellate cyst events compared: index events for Late Cretaceous-Neogene. In: Exon, N.F., Kennett, J.P., Malone, M.J. (Eds), Proceedings of the Ocean Drilling Program, Scientific Results, 189: 1-98.

Yepes, O. 2001. Maastrichtian-Danian dinoflagellate cyst biostratigraphy and biogeography from two equatorial sections in Colombia and Venezuela. Palynology, 25: 217-249. 